\title{
Çocukluk çağı ayak parmak deformiteleri
}

\section{Toe deformities in childhood}

\author{
M. Esat Uygur \\ İstanbul Medeniyet Üniversitesi Tıp Fakültesi, Göztepe Eğitim ve Araştırma Hastanesi, Ortopedi ve Travmatoloji Anabilim Dalı
}

\begin{abstract}
Deformiteleri tanımak, neden olabileceği olası yakınmaları tahmin etmek ve tedavi yolunu çizmek hekimlik sanatında şüphesiz ki önemli bir yer tutmaktadır. Biyomekanik etkenlerin son derece etkin rol aldığı organımız olan "ayak"taki deformiteleri yönetmek zordur ve tecrübe gerektirir. Üstelik bu deformitelerin çocuk yaş grubunda görüldüğü düşünülürse; gelişen, büyüyen, şekil değiştiren özellikte olması nedeniyle daha karmaşık bir hal alabileceği öngörülmelidir. Bu karmaşıklıktan dolayı, ayak parmak deformitelerinin yönetimi her ne kadar temelde Ortopedi ve Travmatoloji uzmanınca yapılıyor olsa da, birinci basamak hekimlerin de deformitelerin fark edilmesi, yönlendirilmesi ve bunlara eşlik edebilecek sorunların akla getirilmesi gibi konularda bilgi sahibi olmaları önerilmektedir. Bu derlemede çocukluk yaş grubunda sık karşılaşılan ayak parmak deformiteleri ve bu deformitelere yönelik tedavi yaklaşımları irdelenmiştir.
\end{abstract}

Anahtar sözcükler: küçük parmak deformiteleri; doğumsal deformiteler; ayak; halluks
To recognize the deformities, to estimate the possible complaints of patients, and to draw the path of treatment precisely has an important place in the art of medicine. Managing the deformities in the "foot", where biomechanical forces play an extremely active role in, is difficult and requires experience. Moreover, when these deformities are thought to be seen in the childhood; it is predicted that it may become more complicated because it has features of developing, growing, and altering of the shape. Because of this complexity, although the management of the toe deformities is mainly performed by Orthopedics and Traumatology specialists, it is suggested that primary care physicians should also be informed on issues such as recognizing, orienting, and bringing about problems accompanying these deformities. In this review, common toe deformities in childhood age group, and treatment approaches for these deformities are discussed briefly.

Key words: lesser toe deformities; congenital deformities; foot; hallux

sürdürebilir. Bazı deformiteler erişkin yaşa dek herhangi bir yakınmaya yol açmayabilir. Buna karşın, deformitelerin bir kısmı iskelet sisteminin gelişmesiyle ve yaşın ilerlemesiyle birlikte yakınmalara neden olur. En sık karşılaşılan yakınma, ayakta nasırlaşma (Şekil 1) ve ayakkabı giymekte zorlanmadır.

Bazı çocukluk çağı ayak parmak deformiteleri tek başına kozmetik sorunlar yaratır. Ancak, özellikle ergenlik dönemindeki bireylerde bu kozmetik sorunlar ciddi psikolojik problemlere yol açabilir. Bu açıdan, deformitelerin iyi tanınması, altta yatan asıl patolojinin ayırt edilmesi ve tedavilerinin doğru planlanması gerekmektedir. Aksi halde, tedavinin geciktirilmesi başka sorunlara neden olabilir ya da cerrahi düzeltme sonrasında istenmeyen ardıl sorunlar, nüks veya başka deformiteler gelişebilir.
Kıvrık parmak gibi ayak parmak deformitelerinin bir kısmı çocukluk çağında kendiliğinden düzelme eğilimi gösterirken, diğer bir kısmı erişkin çağa dek varlığını

- Illetişim adresi: Yrd. Doç. Dr. M. Esat Uygur, Eğitim Mah. Doktor Erkin Cad. Kadıköy, 34732, İstanbul, Türkiye e-posta: esatuygur@gmail.com

- Geliș tarihi: 17 Kasım 2017 Kabul tarihi: 17 Kasım 2017 


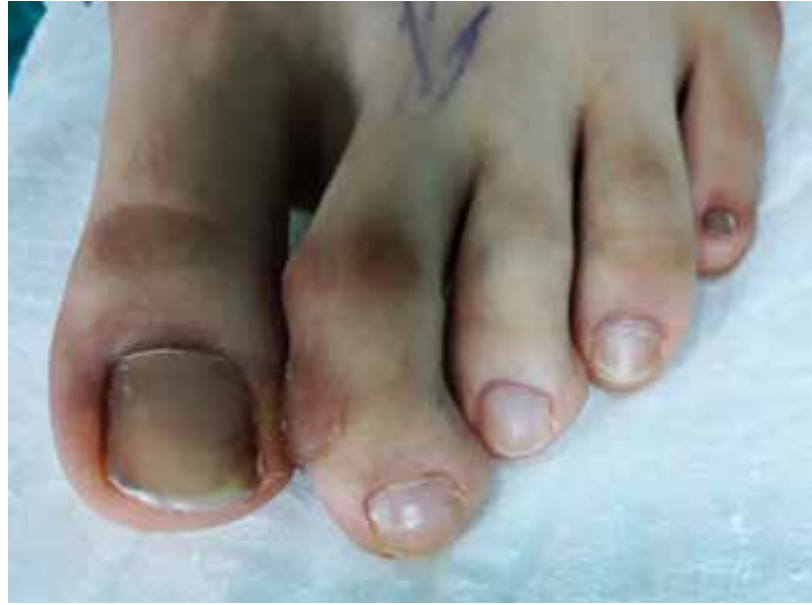

Şekil 1. Ayak parmak deformitelerinin en sık neden olduğu yakınma parmakta gelişen nasırlar nedeniyle ağrı ve ayakkabı giymede zorlanmadır.

Gerçek ayak parmak deformiteleri acil cerrahi müdahale gerektirmezken, özellikle yenidoğan ve süt çocuğu döneminde ayak parmak deformiteleri ile karışan kıl turnike sendromuna (hair tourniquet syndome) dikkat edilmelidir (Şekil 2). Zira kıl turnike sendromunda parmağın nekroza gitmemesi için acil müdahale gereklidir. ${ }^{[1]}$ Tıbbi yazında makrodaktili ile karışabilecek hemanjiyomlar rapor edilmiştir. ${ }^{[2]}$ Parmak beslenmesini bozacak damarsal bir bozukluk ya da hemanjiyom varlığında da lezyonun vücuttan uzaklaştırılması gerekmektedir.

\section{Juvenil Halluks Valgus}

Gelişimini tamamlamamış iskeletteki halluks valgus deformitesine juvenil halluks valgus (JHV) deformitesi adı verilir. Halluks valgus deformitesinde birinci metatars varusa doğru yön değiştirirken, başparmak metatarsofalangeal (MTF) eklemden laterale doğru yön değiştirmektedir (Şekil 3).

JHV, ergenlik döneminde ve kızlarda daha sık görülmektedir. ${ }^{[3]}$ Ülkemizdeki araştırmalarda JHV sıklığının $\% 0,56-3,1$ olduğu gösterilmiştir. ${ }^{[3,4]}$

JHV olgularının erişkin halluks valgusundan bazı farklı yanları bulunmaktadır. Bunlardan ilki, çoğunlukla deformiteye ağrının eşlik etmemesidir. Dolayısıyla, JHV olguları sıklıkla kozmetik yakınmalardan ötürü hekime başvurmaktadırlar. İkinci belirgin fark ise distal metatarsal eklem açısı (DMEA) ile ilişkilidir. DMEA erişkin halluks valgus olgularında çoğunlukla normal iken JHV olgularında artmış olarak izlenmektedir. ${ }^{[5]}$ Ancak JHV'yi çocukluk çağındaki serebral palsinin ya da tarsal koalisyonun eşlik ettiği ağrılı halluks valgustan ayırt etmek gerekir.

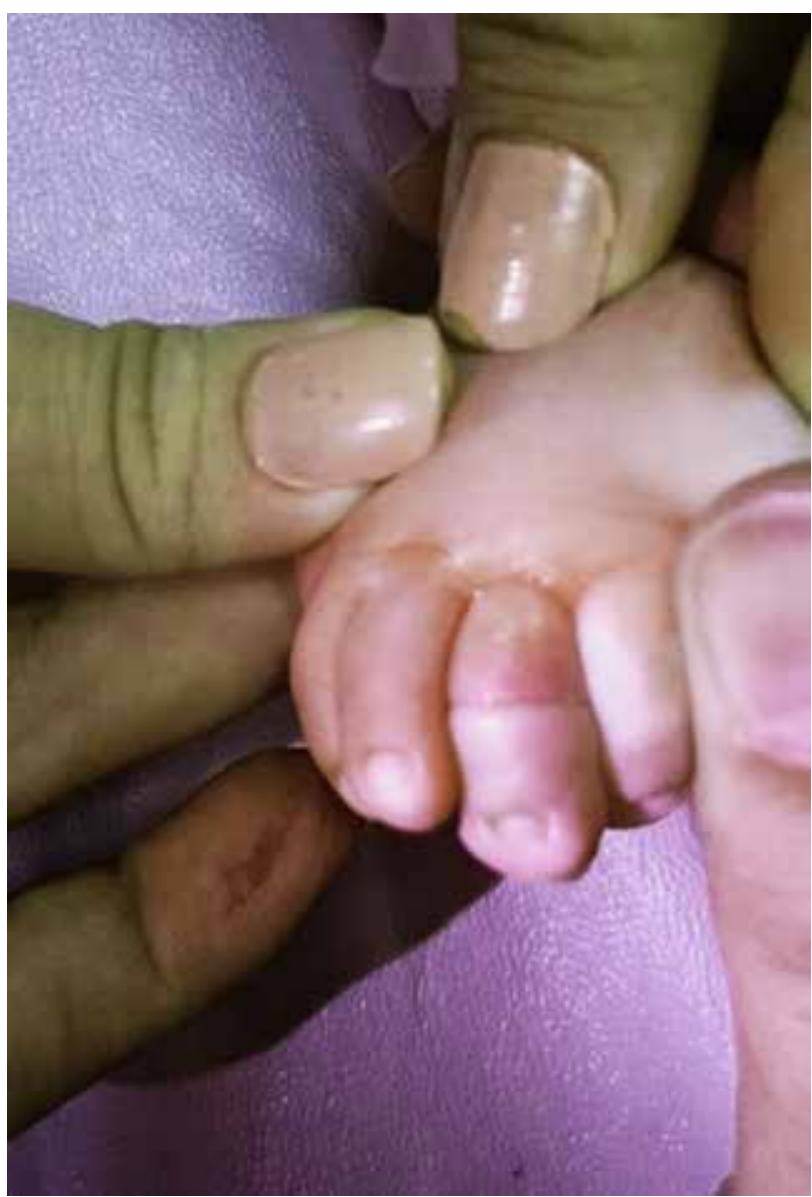

Şekil 2. Kıl turnike sendromu makrodaktili ve daktilit ile karışabilecek bir durumdur. Ayırıcı tanı yapılarak kıl turnike sendromuna acilen müdahale edilmeli, parmak dolaşımı yeniden sağlanmalıdır.

JHV olguları erişkinlere göre daha yüksek nüks riski (\%20-40) taşımaktadırlar. ${ }^{[6]}$ Bunun nedeni JHV'nin etiyolojisinde yatmaktadır. Nitekim JHV olgularında bağ esnekliği, pes planus, metatarsus adduktus, gergin gastrosoleus, birinci sıra aşırı esnekliği gibi eşlik eden biyomekanik nedenler erişkinlere nazaran daha fazla yer tutmaktadır. ${ }^{[7-9]}$

JHV tedavisinde ameliyatsız tedavilerin yeri tartışmalı olmakla birlikte, özellikle başparmak varusunu korumayı sağlayıcı bandajlama önerilebilir. Bu uygulama, bağ esnekliğini sağlaması nedeniyle erişkinlerde olduğundan daha etkindir. Kullanım kolaylığı ve devamlılığı sunması nedeniyle yazarın tercihi; hasta ve yakınlarının beklentilerini yükseltmeden, gece bandajlarını önermek şeklindedir.

JHV olgularında cerrahi tedavinin zamanlaması konusunda epifizlerin kapanmasını beklemek daha doğru 

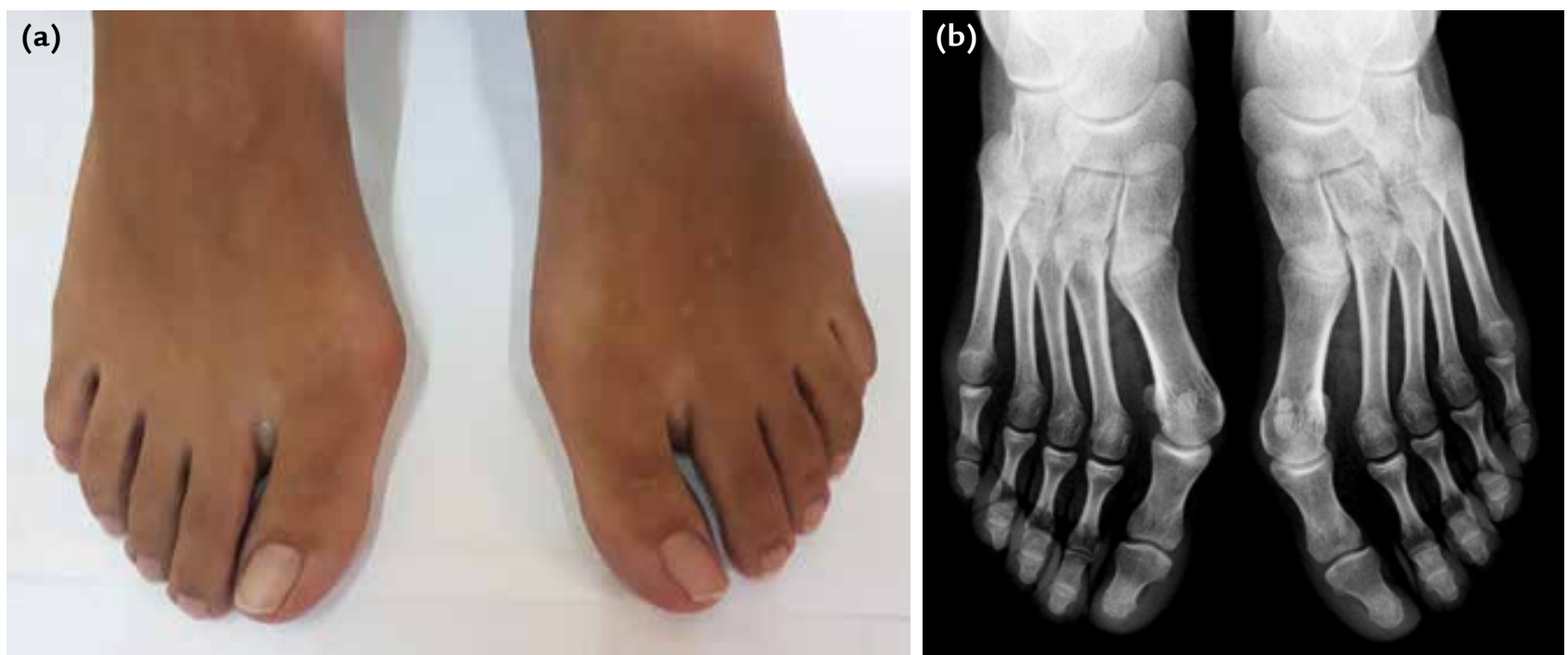

Şekil 3. a, b. On iki yaşında, epifizleri kapanmış bir juvenil halluks valgus olgusu (a) ve radyografisi (b).
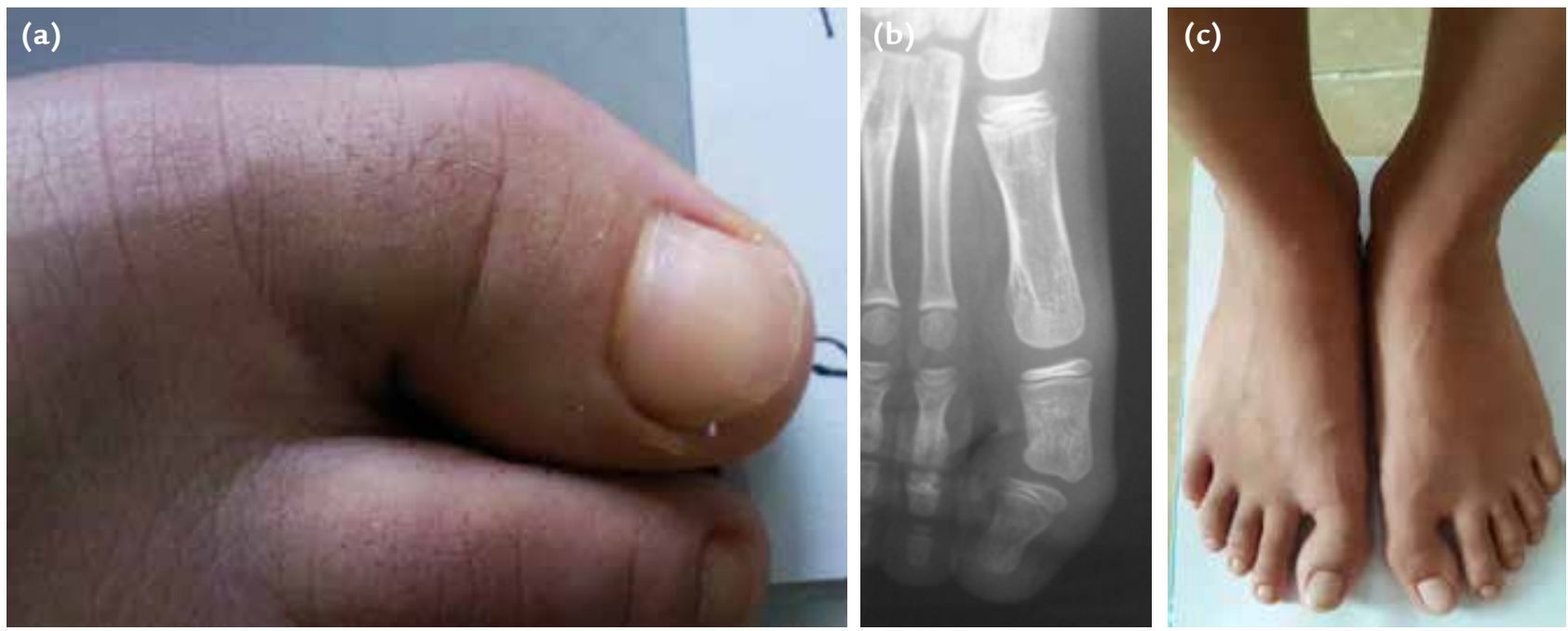

Şekil 4. a-c. Altı yaşında bir olguda halluks valgus interfalangeus deformitesi (a) ve deformiteye ilişkin direkt radyografi. Proksimal falanksın distal eklem yüzündeki valgus deformitesine dikkat ediniz (b). Aynı hastanın 13 yaşındaki takip fotoğrafında deformitenin varlığını sürdürdüğü izlenmektedir (c).

bir yaklaşım olacaktır. ${ }^{[6]} \mathrm{Bu}$ konuda birinci metatars epifizinin -diğerlerinden farklı olarak- proksimalde yer aldığının akılda tutulması gerekir.

Cerrahi seçenekler arasında; mediyal küneiforma mediyalden açık kama osteotomisi, büyüme plağı distalinden metatars proksimalinden mediyalden açık kama/kubbe osteotomisi ve distal metatarsal osteotomiler yer almaktadır. Çocukluk çağında kaynamama ve yumuşak doku sorunları nadir görüldüğünden, metatarsal cisim osteotomileri de güvenle tercih edilebilir. Bunun dışında JHV cerrahi tedavisine lateral hemiepifizyodez ameliyatları tanımlanmış olsa da, büyüme planlamasının zorluğu nedeniyle yaygın olarak kullanılmamaktadır. ${ }^{[6]}$

\section{Halluks Valgus İnterfalangeus}

Halluks valgus interfalangeus, başparmağın distal ve proksimal falanks aksları arasındaki $10^{\circ}$ yi aşan valgus deformitesini ifade eder. ${ }^{[10]}$ Esasen halluks valgus ile ilişkisi yoktur. ${ }^{[8]}$ Bazı olgulardaki deformite, proksimal falanksın distal eklem yüzündeki valgus deformitesi ile ilişkili olabilir (Şekil 4). 


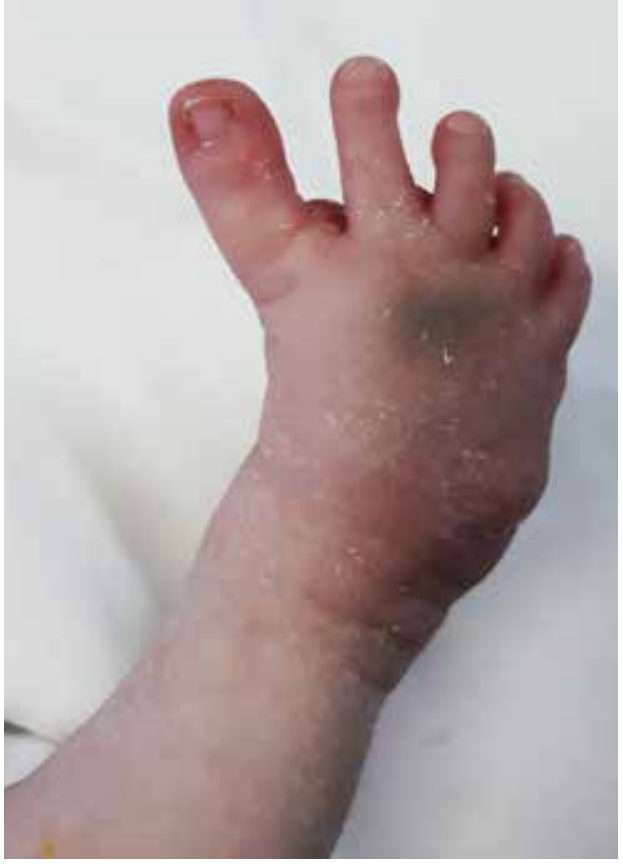

Şekil 5. Doğumsal halluks varus olgusu.
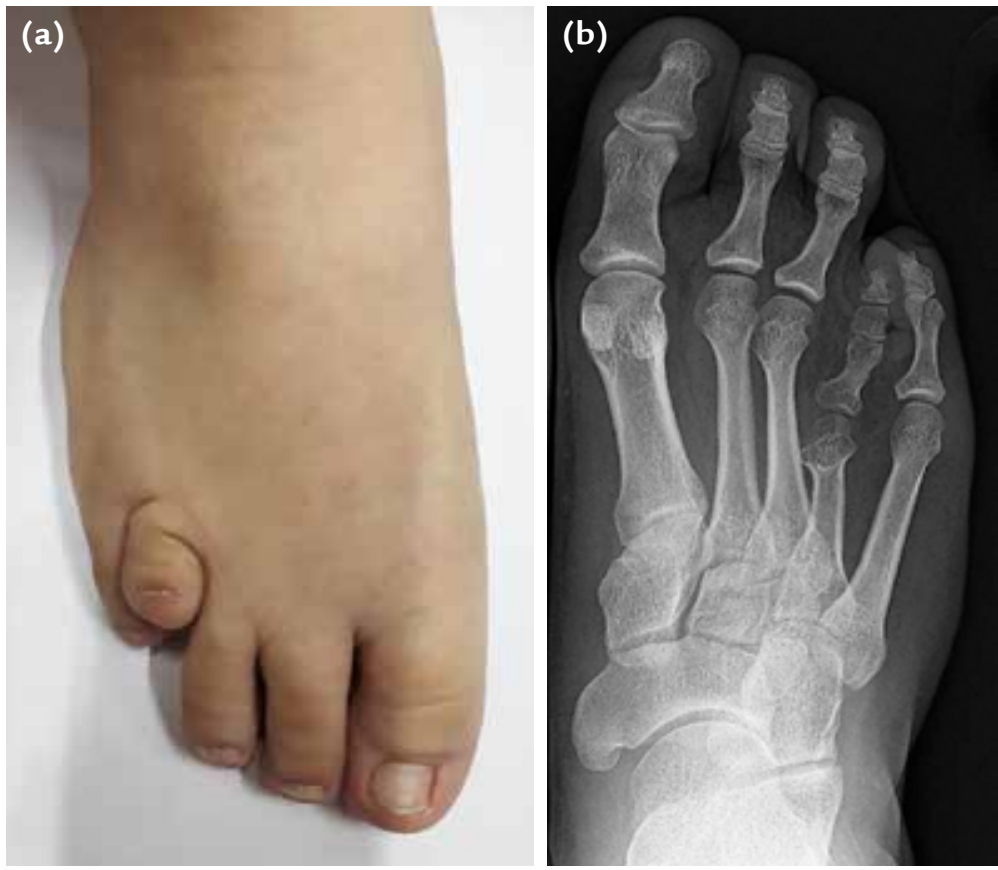

Şekil 6. a, b. Kısa dördüncü metatarsa ait klinik (a) ve radyolojik (b) bir örnek olgu.
Halluks valgus interfalangeus genellikle kozmetik yakınmalara yol açar, ancak ileri deformitelerde yakınmaların oluşma ihtimali de artmaktadır. ${ }^{[10]}$

Cerrahi düzeltme, proksimal falanksa yapılan osteotomiler ile sağlanabilir. Tespit malzemesi olarak ise Kirschner teli, zımba ya da basit dikiş malzemesi kullanılabilir.

\section{Doğumsal Halluks Varus (Atavistik Başparmak)}

Doğumsal halluks varus, oldukça nadir görülen bir deformite olup başparmağın mediyale yön değiştirmesi nedeniyle birinci ve ikinci parmaklar arası mesafenin olağandan fazla olmasını ifade eder (Şekil 5). ${ }^{[11]}$ Çoğunlukla polidaktili, fazla metatars, kısa birinci metatars gibi deformiteler ile beraberdir. ${ }^{[12]}$ Bilinen başlıca nedenleri arasında i) parmak mediyalinden birinci metatatars tabanına yapışan gergin, fibröz, aberran bir bağın eşlik etmesi, ii) delta falanks olarak tanımlanan epifizi ilgilendiren bozukluk (longitidunal epifizyel bracket) nedeniyle gelişen halluks varus, iii) polidaktili gibi lateraldeki yer kaplayıcı lezyonlar nedeniyle gelişen halluks varus olarak sayılabilir.

Cerrahi tedavisinde, gergin mediyal yapıların gevşetilmesi, varsa fibröz bandın çıkarılması ve lateral MTF eklem bağlarının sıkılaştııılması sağlanmalıdır. Bunun yanında, ekstensor hallusis brevis tendonu laterale nakledilebilir. Aksesuvar kemikler eşlik ediyorsa çıkarılmalıdır. ${ }^{[8]}$

\section{Kısa Dördüncü Metatars (Brakimetatarsi)}

Kısa dördüncü metatars, doğrudan parmak deformitesi olmasa da parmak deformitesi şeklinde yansıdığından bu grupta ele alınabilir (Şekil 6). Bilinmeyen bir nedenden ötürü metatars distalinde yer alan büyüme plağındaki bozukluk nedeniyle metatarsın kısa kaldığı düşünülmektedir. ${ }^{[9,13]}$ Etiyolojisinde Turner sendromu, Albright sendromu, Down sendromu gibi genetik nedenler yer alırken, psödohipoparatiroidi ve yaralanmalar gibi kazanılmış nedenler de olabilir. Daha çok kız çocuklarında karşımıza çıkan kısa metatars neredeyse tamamen iki taraflıdır ve genellikle dördüncü metatarsta görülür. Kısalığın ikinci en sık görüldüğü metatars birinci metatarstır ${ }^{[13]}$, ancak her metatarsta görülebilmektedir (Şekil 7).

Dördüncü kısa metatars, çoğunlukla kozmetik kaygılara neden olurken, nadiren dördüncü parmağın dorsale sublukse olmasından dolayı parmakta ağrıya, transfer metatarsaljiye bağlı ayak tabanında ağrı yakınmalarına veya diğer parmaklara dair sorunlara neden olabilir. 

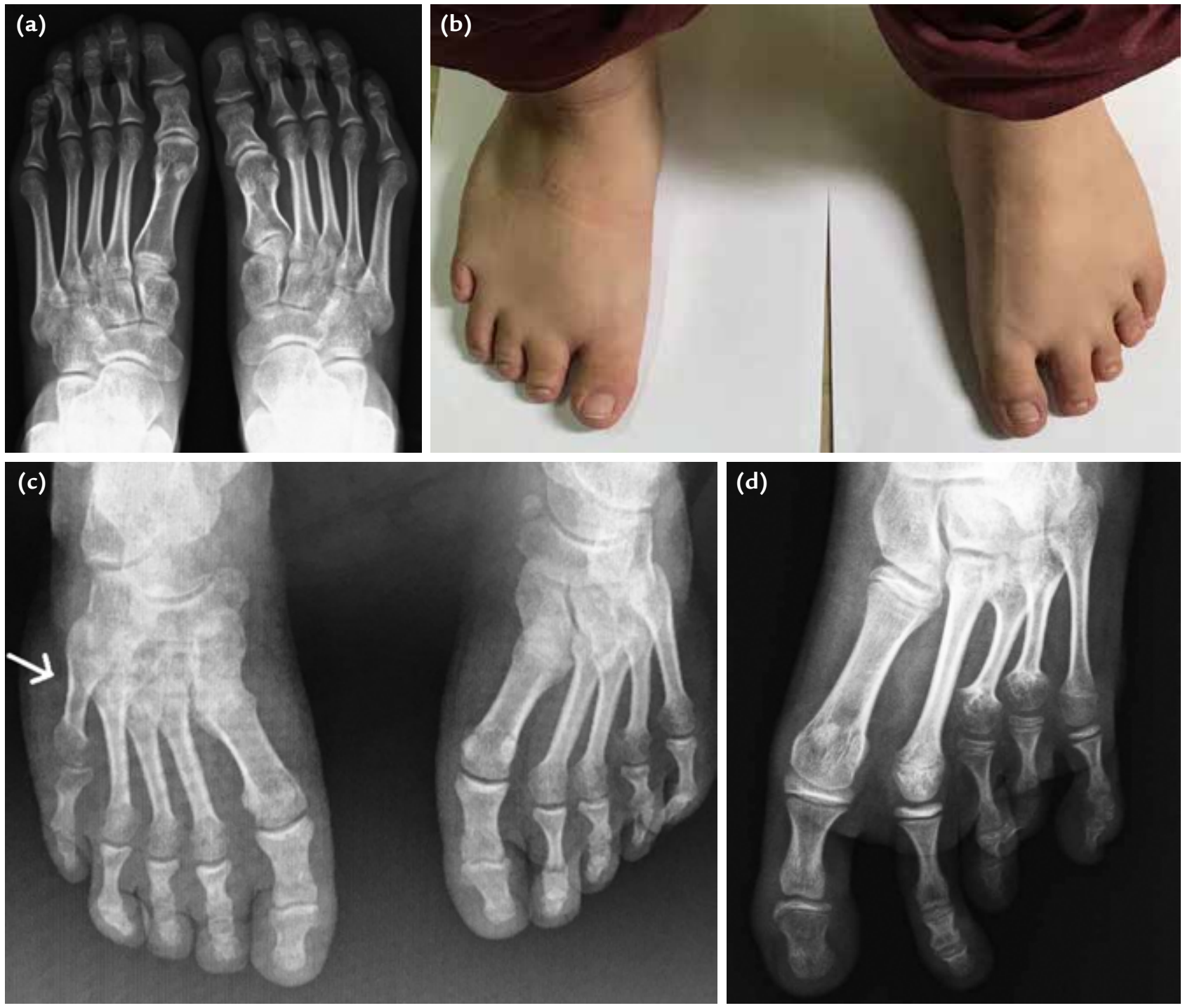

Şekil 7. a-d. Kısa metatars deformitesi en sık dördüncü metatarsta görülürken (a), bunu 1. metatars kısalığı takip eder (17 yaşında kız hasta) (b). Ancak nadiren diğer metatarslarda da kısalık görülebilir. On yaşındaki bu kız olguda sağ ayak beşinci metatarsta (ok) (c) ve yedi yaşında bir kız hastada hem 3. hem 4. metatarslarda kısalık izlenmektedir (d).

Metatars kısalığının yaşla birlikte artması, diğer parmak deformitelerinin ortaya çıkmasına zemin hazırlamaktadır. Böyle bir durumda, eksternal fiksatör yöntemiyle peyderpey yahut otogreft kullanılarak akut olarak metatarsı uzatarak parmak uzunluğu sağlanmalıdır. Dördüncü metatarsa uzatma sağlanırken hedef, dördüncü metatars başını birinci metatarsa hizalamaktır. On beş mm'den ya da metatars uzunluğunun \%40'ından fazla uzatmalarda ardıl sorunların artacağı akılda tutulmalıdır.[13] Osteotominin az-girişimsel yöntemlerle yapılması, asgari damar hasarına yol açar ve bu şekilde osteogenezin başarısı arttırılmış olur.

\section{Kıvrık Parmak \\ (Klinodaktili, Curly Toe, Underlapping Toe)}

Fleksiyon ve varus deformitesinin birlikte olduğu, parmağın mediyaldeki parmağın altına girdiği şekil bozukluğudur (Şekil 8). En sık 3. ve 4. parmaklarda görülür. ${ }^{[5,8]}$ Nedeni tam olarak aydınlatılamamıştır, ancak fleksör dijitorum longus ve brevis tendonlarının aşıı gerginliğinden kaynaklandığı düşünülmektedir. ${ }^{[8]}$ Genellikle aile öyküsü müspettir. Olguların dörtte birinde, deformitenin bebeklik çağında kendiliğinden düzelmesi beklenir. ${ }^{[8]}$ Düzelme görülmeyen hasta grubunda genellikle şikayet yaratmazken, var olan yakınmalar çoğu zaman 

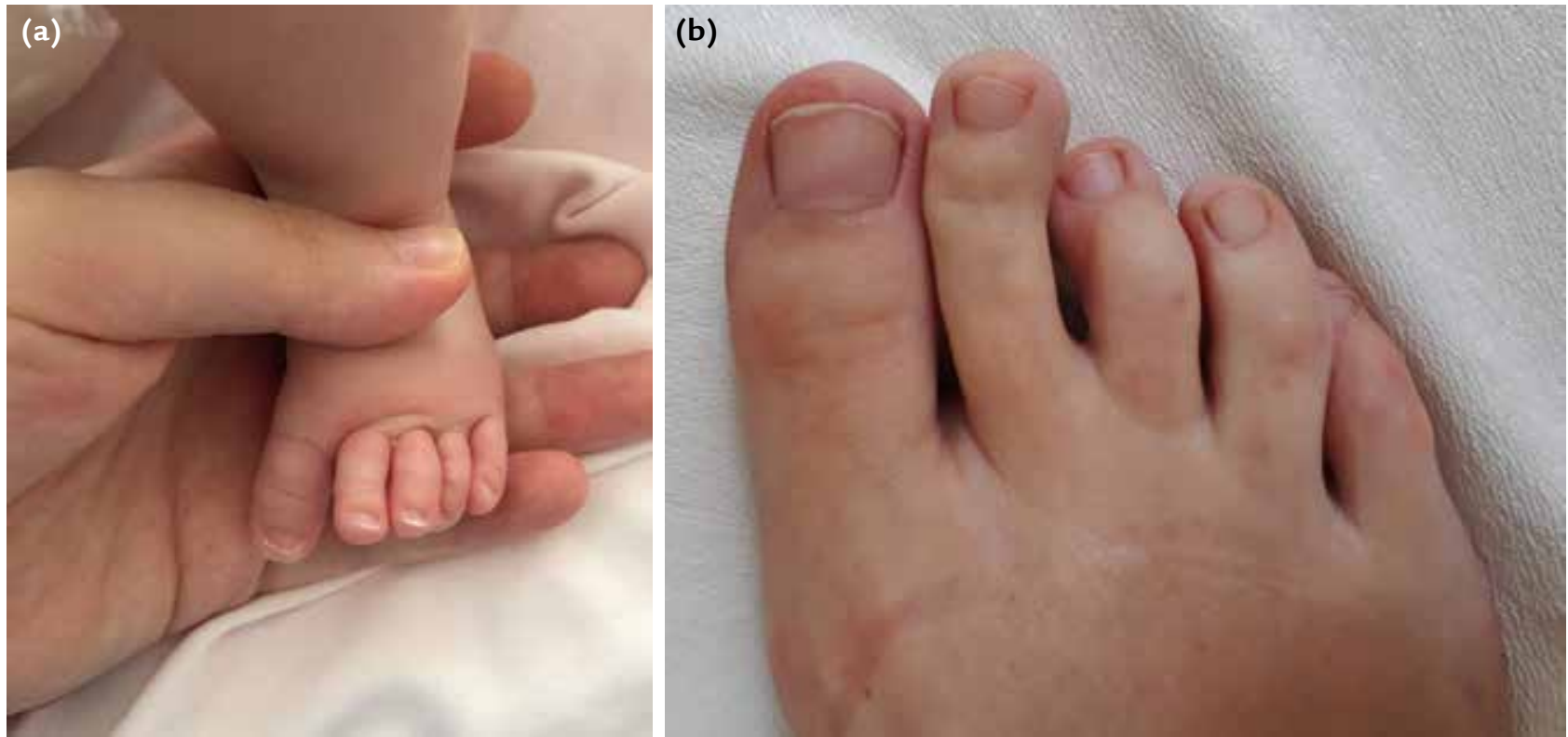

Şekil 8. a, b. Bir aylık bebekte (a) ve 16 yaşındaki genç kızda (b) izlenen iki ayrı olguya ait kıvrık parmak deformitesi.
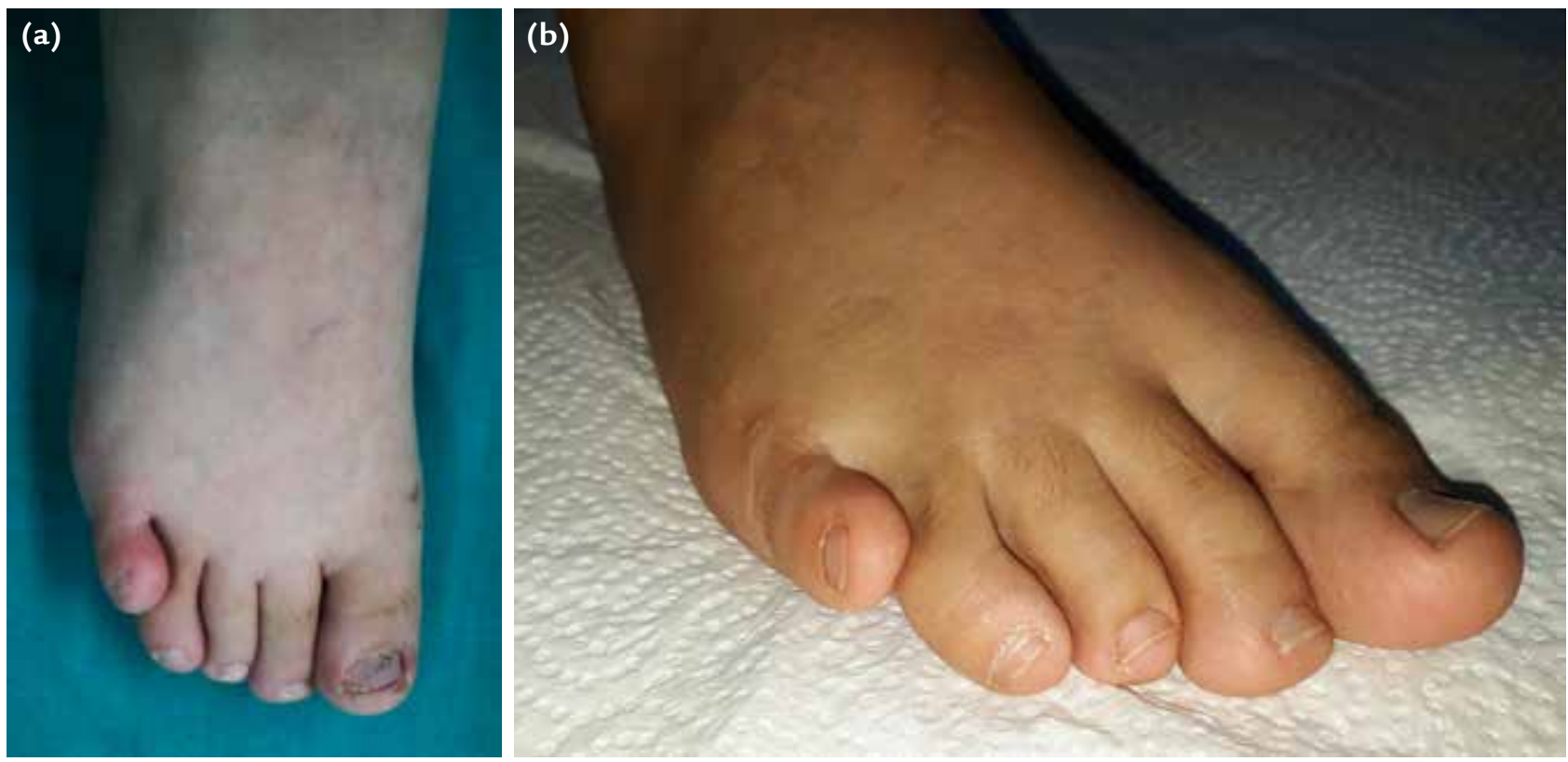

Şekil 9. a, b. Küçük parmak varus deformitesine sahip beş yaşındaki bir kız hastanın ameliyat öncesi (a) ve ameliyattan beş yıl sonraki takibine ait fotoğraflar (b).

ortaya çıkan nasırlar nedeniyle ayakkabı giyememektir. Deformite semptomatik ise cerrahi tedavi olarak fleksör tenotomi yeterlidir. Ancak tenotomiyi planlarken, parmak deformitesinin ayak bileği hareketlerine bağlı olup olmadığı muayene edilmelidir. Deformitenin fleksör tendon gerginliğine bağlı olduğu düşünülen durumlarda, ayak bileği fleksiyona alındığında tendon gerginliği azaldığından, deformitenin düzelmesi beklenir.

\section{Küçük Parmak Varus Deformitesi}

(Doğumsal Dijitus Minimus Varus, Overlapping Toe)

Beşinci parmağın adduksiyon ve dorsifleksiyonu ile dördüncü parmağın üzerine binmesi durumudur. Üst üste binen beşinci parmak deformitesi olarak da bilinir (Şekil 9b ve Şekil 10). Genellikle aileseldir ve nadiren yakınmalara neden olur. ${ }^{[12]}$ 


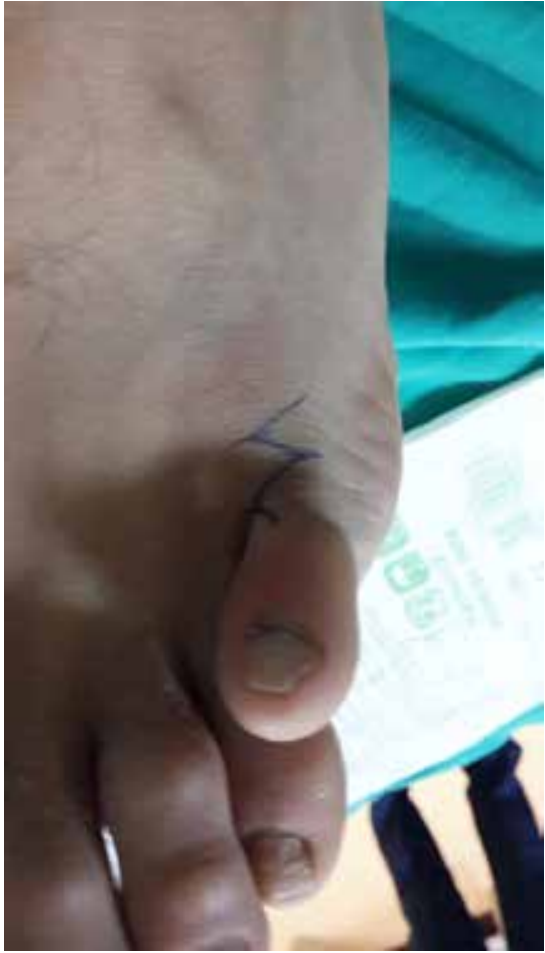

Şekil 10. On yedi yaşındaki erkek bir hastaya ait küçük parmak varus deformitesinin ameliyat öncesi görüntüsü.
Bantlama tedavilerinin yarar sağlamadığı bilinmektedir. Ayakkabı giymekte zorlanma yakınmaları ya da ağrılı parmak nasırları ortaya çıktığında cerrahi tedavi düşünülmelidir. ${ }^{[8]} \mathrm{Bu}$ konuda Butler yöntemi ekstensor dijitorum longus tenotomisi ve MTF eklem kapsülünün gevşetilmesini tanımlarken, McFarland yöntemi Butler'e ek olarak proksimal falanksın uzaklaştırılması ve beşinci parmağın dördüncüye sindaktilizasyonu olarak tanımlanmıştır. ${ }^{[8]}$ Nüks oranı yüksek olduğundan, McFarland yöntemi daha makul sonuçlar vermektedir.

\section{Kalkık parmak (Cock-up Toe) Deformitesi}

Kalkık parmak deformitesi parmağın MTF eklemden aşıı dorsifleksiyonu olarak tanımlanır. ${ }^{[14]}$ Parmak fleksörlerindeki yetmezlik neticesinde ekstensor tendonun hakimiyet kazanması nedeniyle gelişir. Genellikle başparmakta oluşur, ancak beşinci parmakta da görülebilir. Başparmaktaki kalkık parmak deformitesi daha ileri yaşlarda genellikle halluks valgus cerrahisinin bir ardıl sorunu olarak karşımıza çıkarken, çocukluk çağında serebral palsi gibi nöromusküler bozukluklara ikincil olarak gelişmektedir (Şekil 11. a, b).

Tedavisi, ekstensor tendon uzatılması ve/veya interfalangeal artrodez ile sağlanır (Şekil 11. c, d).
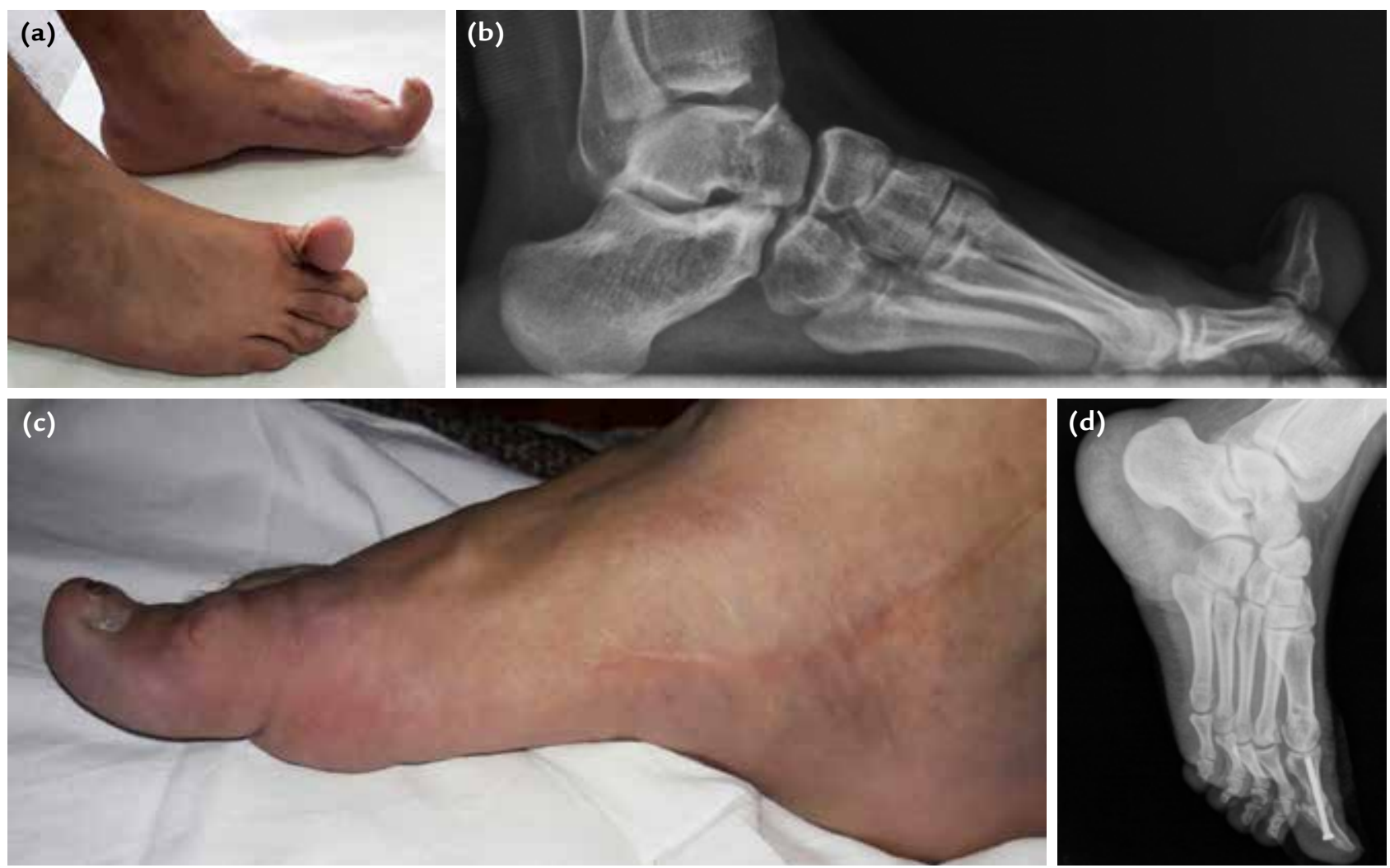

Şekil 11. a-d. Nörolojik nedenli kalkık parmak deformitesine sahip 17 yaşında bir olgunun klinik görüntüsü (a). Aynı hastanın ameliyat öncesi direkt grafi örneği (b). Ekstensor tenotomi ve interfalangeal artrodez sonrası klinik görünüm (c) ve olgunun ameliyattan bir yıl sonraki direkt grafi görüntüsü (d). 


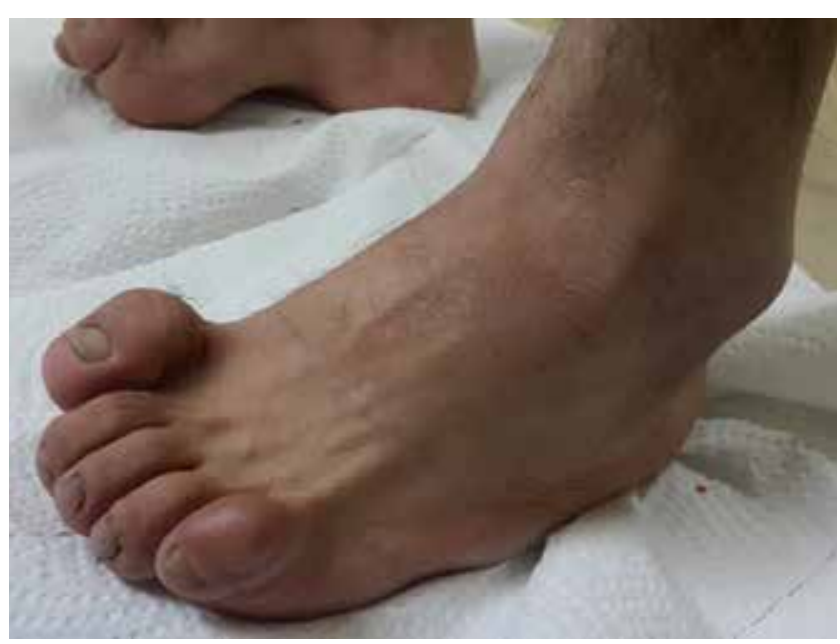

Şekil 12. Pes cavus deformitesine eşlik eden özellikle ikinci parmakta pençe parmak deformitesi izlenmektedir.

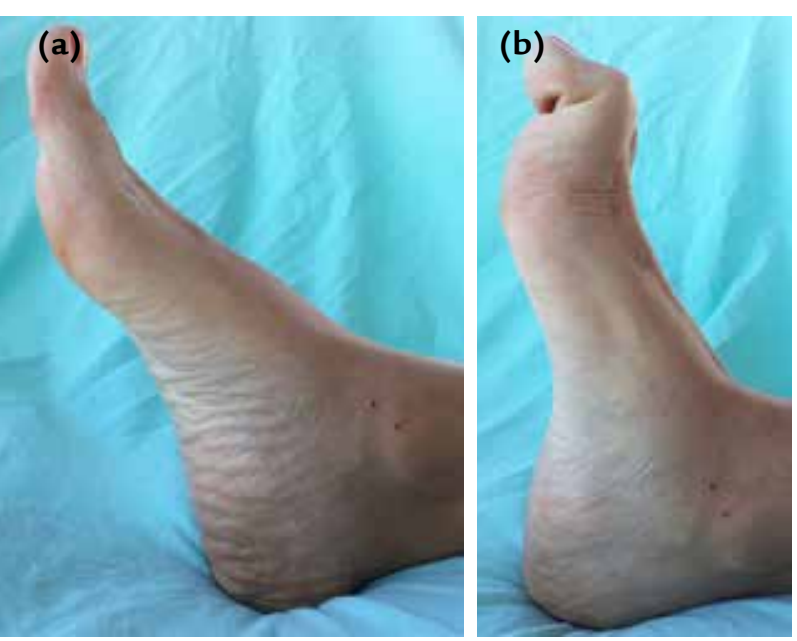

Şekil 13. a, b. Checkrein deformitesi. Ayak bileği fleksiyon pozisyonunda başparmak normalken (a), ayak bileği dorsifleksiyona alındığında fleksör hallucis longus tendonunun gerginliğine bağlı olarak başparmakta metatarsofalangeal eklemde dorsifleksiyon ve interfalangeal eklemde fleksiyon deformitesi izlenmektedir (b).

deformitesini çekiç parmaktan ayıran özellik DIF eklemdeki fleksiyon defomitesidir.

\section{Checkrein Deformitesi}

Dinamik pençe parmak deformitesine özel olarak verilen isimdir. ${ }^{[15]}$ Ayak bileği ekstansiyona alındığında fleksör hallucis longus (FHL) tendonunun ekskürsiyonunun kısıtlanması ve başparmağın kendiliğinden fleksiyona gelmesi durumudur (Şekil 13). FHL genellikle tek başına etkilenirken, bazı durumlarda FHL'ye fleksör dijitorum longus tendonu da katılabilir.

Checkrein deformitesinin nedeni geçirilmiş yaralanmalardır. Etiyolojisinde i) FHL'nin tibia, kalkaneus ya da talus kırıkları sonrası geliş̧en kaynama (kallus) dokusu içerisinde hapsolması, ii) FHL'nin nedbe dokusu içerisinde hapsolması, iii) derin kompartmanında gelişen kompartman sendromu nedeniyle kas gövdesindeki nedbe dokusu nedeniyle kasın kısalması ve iv) yaralanmayı takiben muskulotendinoz bölgede kas ile tibia arasında gelişen yapışıklıklar yer almaktadır. ${ }^{[15-17]}$

Tedaviye yönelik ilk adım, FHL'nin durumunu netleştirmek amacıyla ultrasonografi ve manyetik rezonans görüntülemeleri elde edilmesidir. Nedene yönelik yapışıkıkların cerrahi olarak giderilmesi, tendonun Z-plasti ile uzatılması ya da fleksör tenotomiye ek olarak başparmak interfalangeal artrodez yöntemi tanımlanmıştır. ${ }^{[17]}$ 

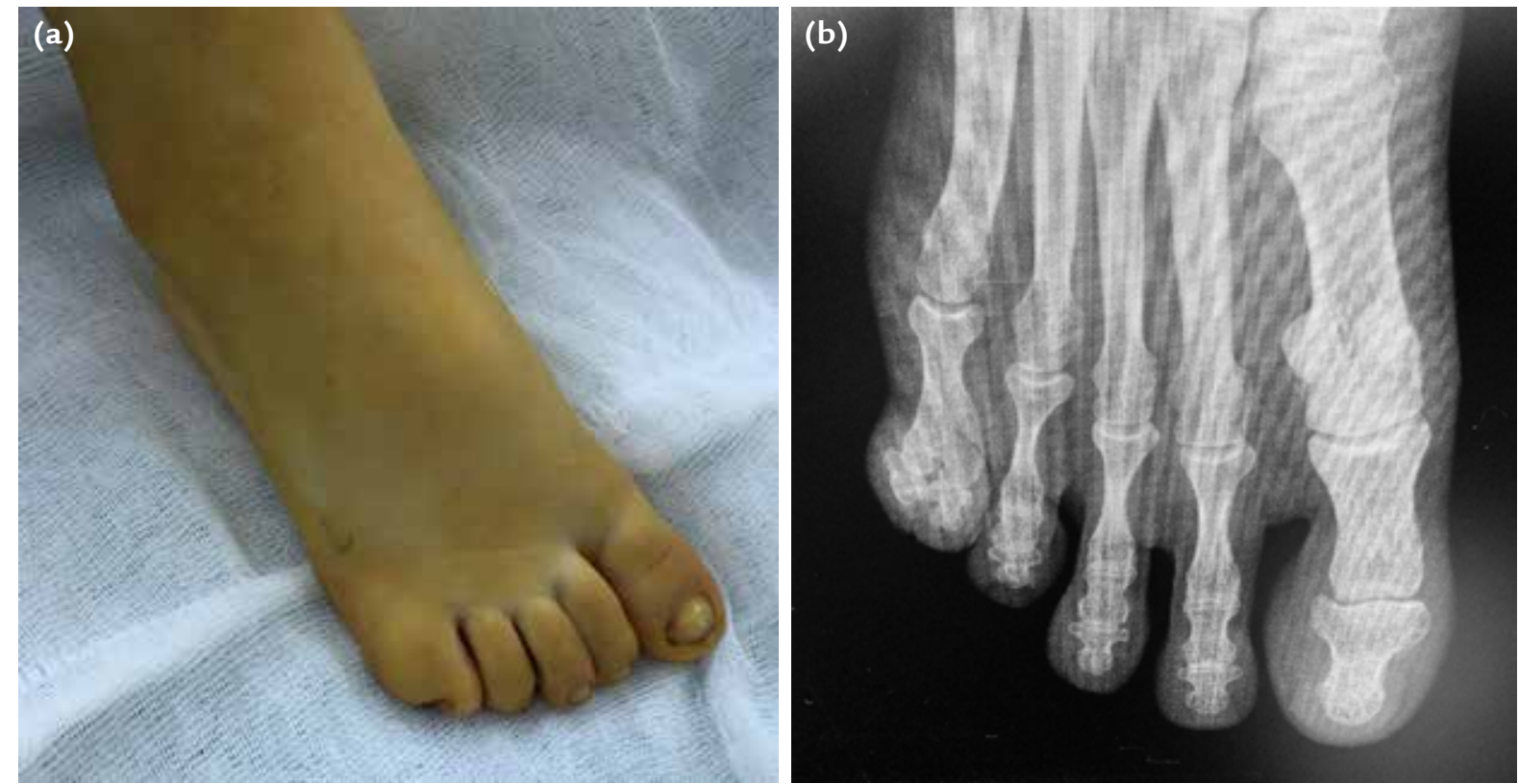

Şekil 14. a, b. Postaksiyel polidaktilinin klinik (a) ve radyolojik (b) görüntüleri.

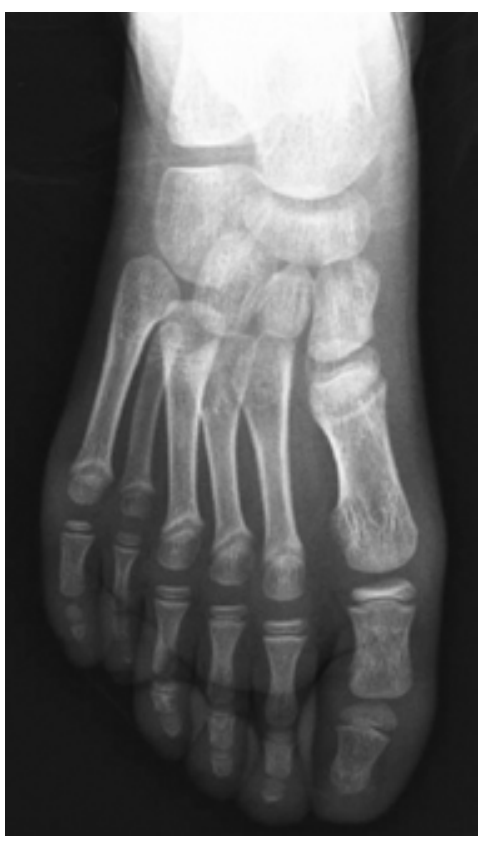

Şekil 15. Yedi yaşında bir olguya ait postaksiyel polidaktili radyografisi.

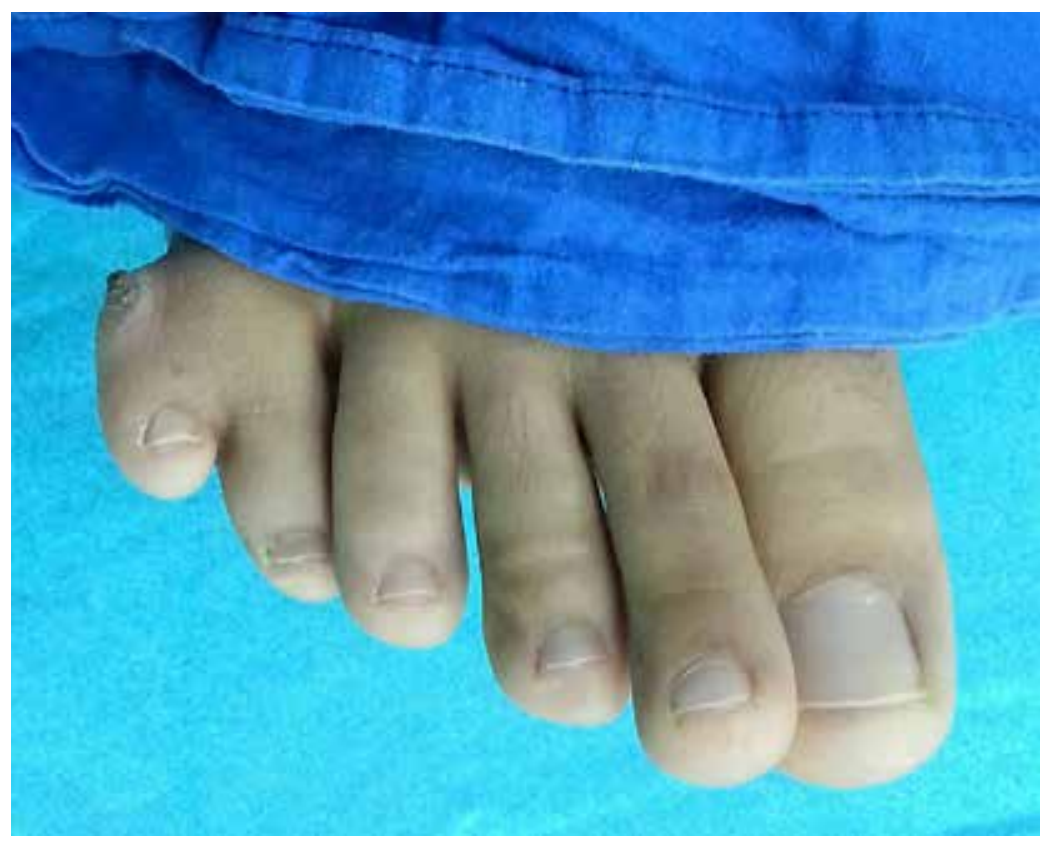

Şekil 16. Sadece kozmetik yakınmalara neden olan polidaktili.

\section{Fazla Parmaklılık (Polidaktili)}

Polidaktili, embriyonik dönemde iskelet sistemindeki duplikasyon nedeniyle oluşur. Polidaktili konusunda farklı sınıflama sistemleri geliştirilmiştir. íkinci metatarsın mediyal ve lateralinde olmasına göre sırasıyla pre- ve postaksiyel polidaktili olarak adlandırılır. İkinci, üçüncü ve dördüncü sırada görülen duplikasyonlar, santral polidaktili olarak da isimlendirilmektedir. Ayakta görülen polidaktililerin \%80'ini beşinci parmak lateralindeki postaksiyel polidaktili oluşturur (Şekil 14, Şekil 15 ve Şekil 16). ${ }^{[8,12,13]}$

Küçük yaşlarda kemikleşmenin tam olmaması nedeniyle radyolojik görüntülemeler sınıflamanın tam olarak yapılmasında yetersiz kalır. Bu konuda Lee ve ark. klinik, 

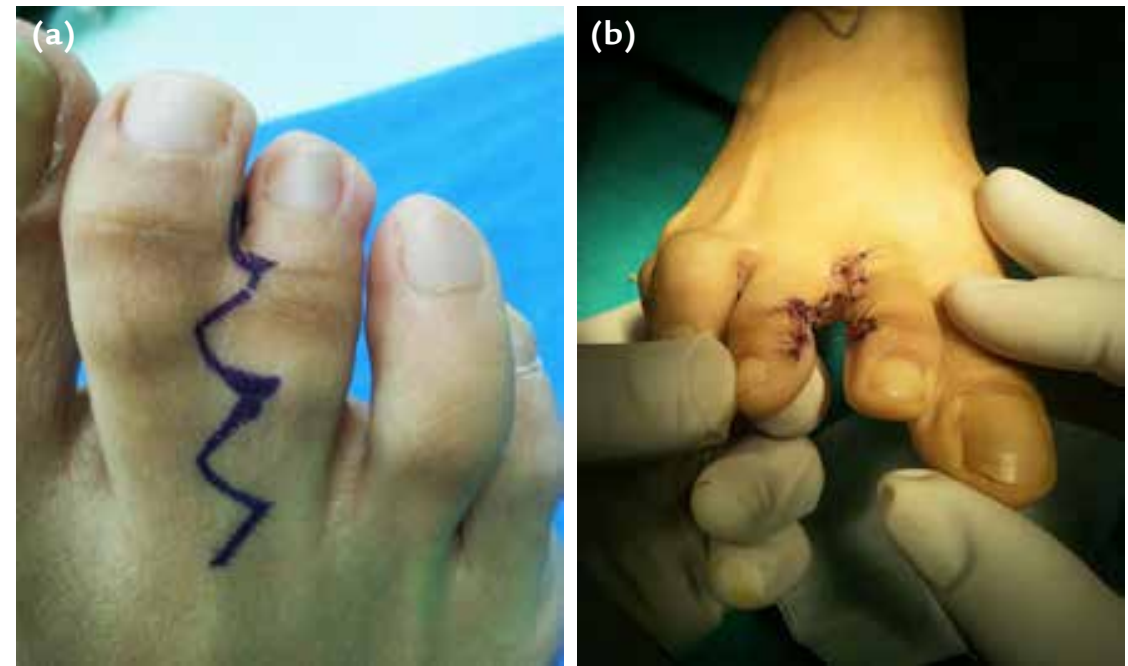

Şekil 17. a, b. On yedi yaşında kız hastada izlenen basit yapışık parmaklılık (a) ve ameliyat sonrası görünümü (b).
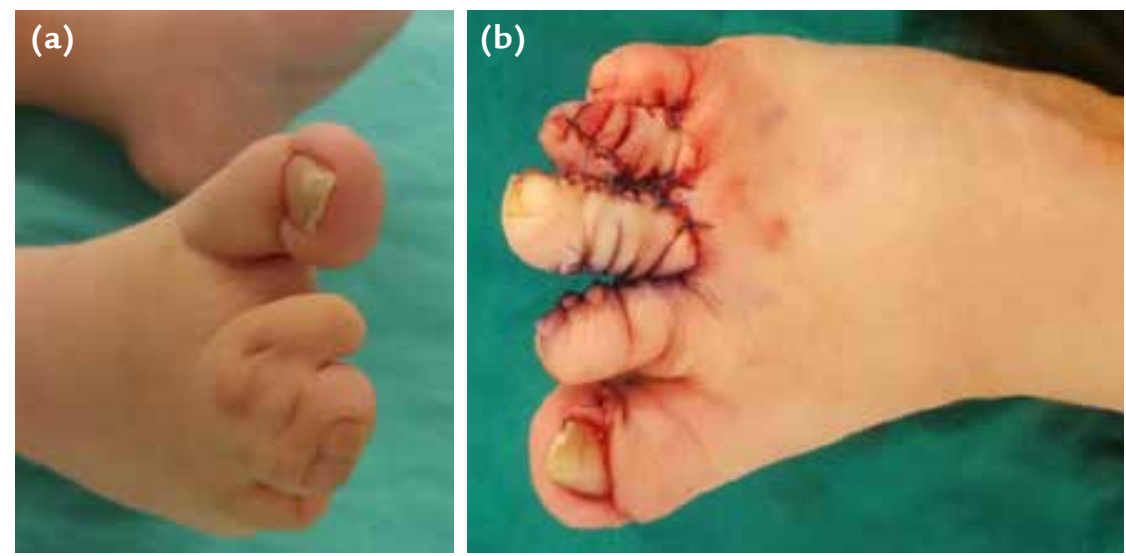

Şekil 18. a, b. Üç yaşında kız bir hastanın basit yapışık parmaklılık (a) ve ameliyat sonrası görüntüsü (b).

radyolojik ve ameliyat sırasındaki bulguları dikkate alarak daha kullanışlı bir sınıflama öne sürmüşlerdir. ${ }^{[13]}$

Postaksiyel polidaktilide eğer parmak tam olarak oluşmuş ve eklemleşiyorsa A tipi; güdük (rudimenter) bir parmak söz konusu ise $B$ tipi polidaktili olarak isimlendirilir.

Otozomal baskın olarak geçiş gösterebilir. Bu nedenle, aile öyküsü genellikle müspettir. ${ }^{[12]}$

Fazla parmağın uzaklaştırılması için önerilen zamanlama, yürüme ve ayakkabı giymeye başlamadan hemen öncesidir. Bu nedenle, çocuk bir yaşına basmadan ameliyat edilmesi uygun olur.

Polidaktilinin tedavisinde temel kural, normal anatomiye en uygun olacak şekilde, daha az gelişmiş parçanın vücuttan uzaklaştırılması şeklindedir. Bu bağlamda, preaksiyel polidaktilinin cerrahi sonuçlarını kestirmek daha zordur. En uygun yumuşak doku dengesini sağlamak, ileride gelişebilecek halluks valgus, pes planus ya da halluks varus gibi deformiteleri önlemek açısından önemlidir. Postaksiyel polidaktilide ise cerrahi sonuçlar daha yüz güldürücüdür. ${ }^{[12]}$

\section{Eksik Parmaklılık (Oligodaktili)}

Doğumsal parmak yokluğudur. Fibular hemimeli gibi daha proksimaldeki agenezler ile birlikte olabilir. Parmakta tek başına olduğunda tedavi gerektirmeyebilir.

\section{Yapışık Parmak, Perdeli parmak (Sindaktili)}

Yapışık parmaklılıkta parmaklar arasındaki perdelenme, çoğunlukla proksimal falankslarda olurken (kısmi, inkomplet), bazen tüm parmağı da etkileyebilir (tam, komplet). En yaygın olarak ikinci ve üçüncü parmaklar arasındadır (Şekil 17 ve Şekil 18). 

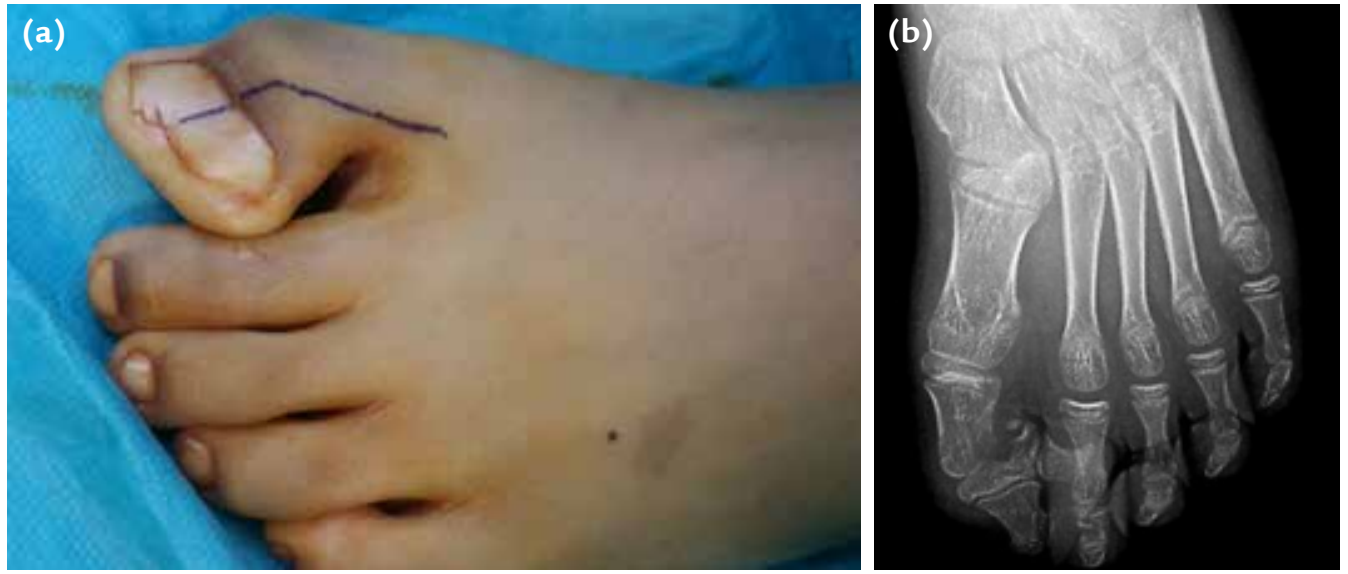

Şekil Şekil 19. a, b. On altı yaşında bir erkekte görülen preaksiyel polisindaktili görüntüsü (a) ve olguya ait direkt grafi (b).

(a)

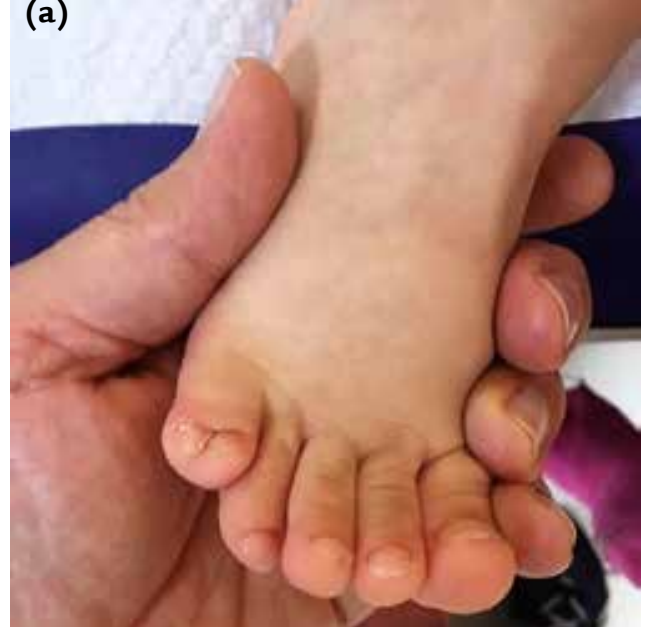

(b)

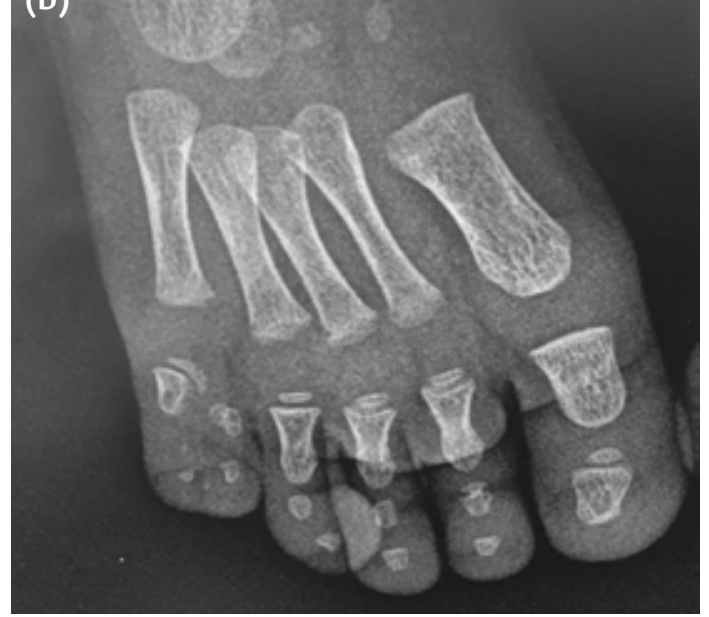

Şekil 20. a, b. Üç yaşında bir kız çocuğunda izlenen postaksiyel polisindaktili görüntüsü (a) ve olguya ait direkt grafi (b).

Parmak yapışıklığına kemiğin de eşlik etmesi dikkate alınarak, basit ve karmaşık (kompleks) olmak üzere ikiye ayrılır. Basit yapışık parmaklılık salt kozmetik sorun yarattığından tedavi gerektirmez. Karmaşık sindaktili özellikle Apert sendromunda görülür. ${ }^{[8]}$

Bazı durumlarda polidaktili ile birlikte görülebilir ki bu durumda polisindaktili olarak anılır (Şekil 19 ve Şekil 20). Postaksiyel polisindaktili durumunda ayağın dış yan kenarını korumak ve insizyon skarı gelişimini önlemek amacıyla mediyaldeki parmağın çıkarılması düşünülmelidir. ${ }^{[12]}$

\section{Dev Parmaklılık (Makrodaktili)}

Parmak yapılarındaki aşıı büyüme nedeniyle ortaya çıkan deformitedir. Sıklıkla ikinci ve üçüncü parmakları etkiler. Bazen metatars tutulumu ile birliktedir.
Nörofibromatozis ve hemanjiyomatozis gibi farklı sendromlara eşlik edebilir. ${ }^{[12]}$

Kararlı (statik) ve ilerleyici olmak üzere iki tip dev parmaklııı vardır. Kararlı tipte doğumda var olan dev parmaklılık diğer parmaklarla orantılı olarak büyürken, ilerleyici tipte deformite erken çocukluk çağında belirginleşmeye başlar ve diğer parmaklara göre daha hızlı büyür. ${ }^{[13]}$

Semptomatik olmasına göre, cerrahiyi ileriki yaşlara bırakmadan gerçekleştirmek gerekir. Kararlı tipte epifizyodez ya da artrodez önerilir. Buna karşın, ilerleyici tipte parmak ampütasyonu daha uygundur. Epifizyodezin deformiteyi uzun dönemde düzelttiği ve ayak genişliğini daraltmadığı akılda tutulmalıdır. Bu nedenle, sıra (ray) ampütasyonu ile işlevsel ve kozmetik açıdan daha kabul edilebilir sonuçlar elde edilebilir. ${ }^{[12]}$ 

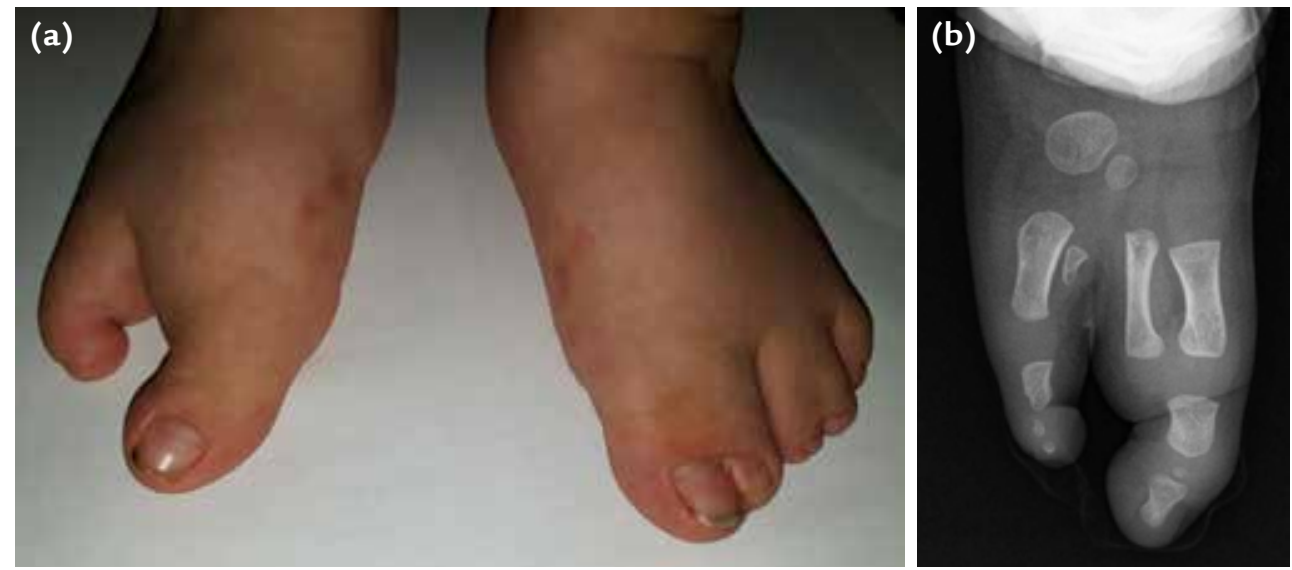

Şekil 21. a, b. Sağda yarık ayak deformitesine ait klinik (a) ve radyolojik (b) görüntüler. Aynı hastanın sol ayak parmaklarında yapışık parmaklılık dikkati çekiyor.

\section{Yarık Ayak, Ayrık Ayak \\ (Split Foot, Ektrodaktili, Cleft Foot)}

Yarık ayak deformitesi 1/90.000 oranında görülen nadir bir deformitedir. Otozomal baskın genetik geçiş gösterir (Şekil 21). Yarık ayak tanımı birinci ve beşinci metatarslar arasındaki bir/birkaç metatarsın ve parmakların kısmi ya da tam yokluğunu ifade eder.

Yarık ayak deformitesi salt cildi ilgilendiren en basit tipten, üç metatarsın parmaklarla birlikte yokluğuna dek değişen bir yelpaze ile karşımıza çıkabilir. Neden olduğu yakınmalar değişkenlik gösterdiğinden, önerilen tedavi de hastaya özgüdür. Cerrahi tedavinin ama$\mathrm{cl}$, daha kabul edilebilir bir görüntüye sahip olan, işlevsel bir ayak oluşturmaktır. Talusan ve ark., yarık ayağın mediyal ve lateraldeki metatarslarını düğme tekniği ile birbirine yaklaştırarak ortasındaki yarığı kapatacak şekilde cilt rekonstrüksiyonu önermişlerdir. ${ }^{[18]}$

\section{KAYNAKLAR}

1. Uygur E, Çarkçi E, Ünkar E. Can washing socks without flipping inside out cause hair tourniquet syndrome? A claim with two case reports. J Pediatr Orthop B 2017;26(2):193-4. Crossref

2. Boulavsky JL, Browne LP, Brandon K, Mawad ME, Phillips WA, Metry D. Congenital swelling of the toe in a 3-monthold boy. Pediatr Dermatol 2014;31(1):103-4. Crossref

3. Uğraş AA, Kaya i, Sungur i, Ertürk A, Yücel B, Çetinus E. Screening of hand and foot anomalies in school children of Fatih district, İstanbul city. J Curr Pediatr 2011;9:60-2.

4. Özerdemoğlu RA, Yorgancıgil H, Deveci K, Yalçınkaya S. ilkokul ögrencilerinde ortopedik semptom ve deformite taraması. Acta Orthop Traumatol Turc 1996;(1):168-74.

5. Baş EG, Aktekin CN. Ayağın Doğuştan ve Kazanılmış Deformiteleri. In: Çullu E, editör. Çocuk Ortopedisi. İstanbul: Bayçınar; 2012. p.199-242.

6. Davids JR, Mcbrayer D, Blackhurst DW. Juvenile hallux valgus deformity surgical management by lateral hemiepiphyseodesis of the great toe metatarsal. J Pediatr Orthop 2007;27(7):82630. Crossref
7. Chou LB, Dieter AA, Aronson J KD. Orthopaedic knowledge update foot and ankle. In: Pinzur MS. Orthopaedic Knowledge Update: Foot and Ankle. 4th ed. Rosemont, IL: American Academy of Orthopaedic Surgeons; 2008. p.238-42.

8. Ricco Al, Richards BS, Herring JA. Disorders of the foot. In: Herring JA. Tachdjian's Pediatric Orthopaedics. Philadelphia: Saunders; 2013. p.833-62.

9. Fahim R, Thomas Z, DiDomenico LA.. Pediatric forefoot pathology. Clin Podiatr Med Surg 2013;30(4):479-90. Crossref

10. Cansü E. L-shaped big toe: a case of severe hallux valgus interphalangeus. J Am Podiatr Med Assoc 2009;99(3):244-6.

11. Shim JS, Lim TK, Koh KH, Lee DK. Surgical treatment of congenital hallux varus. Clin Orthop Surg 2014;6(2):216-22. Crossref

12. Dobbs MB, Beaty JH. Congenital foot deformities. In: Coughlin MJ, Saltzman CL, Anderson RB, editors. Mann's Surgery of the Foot and Ankle, 9th ed. Philadelphia: Elsevier Saunders; 2013. p.1856.

13. Lee HS, Lee WC. Congenital lesser toe abnormalities. Foot Ankle Clin 2011;16(4):659-78. Crossref

14. Coughlin MJ, Anderson RB. Hallux valgus. In: Coughlin MJ, Saltzman CL, Anderson RB, editors. Mann's Surgery of the Foot and Ankle, 9th ed. Philadelphia: Elsevier Saunders; 2013. p.296-7.

15. Fitoussi F, Ilharreborde B, Guerin F, Souchet P, Penneçot GF, Mazda K. Claw toes after tibial fracture in children. J Child Orthop 2009 Oct; 3(5):339-43. Crossref

16. Boszczyk A, Zakrzewski P, Pomianowski S. Hallux checkrein deformity resulting from the scarring of long flexor muscle belly - case report. Ortop Traumatol Rehabil 2015;17(1):7Crossref

17. Holcomb TM, Temple EW, Barp EA, Smith HL. Surgical correction of checkrein deformity after malunited distal tibia fracture: a case report. J Foot Ankle Surg 2014;53(5):631-4. Crossref

18. Talusan PG, Telles C, Perez JL, Reach JS Jr. Treatment of cleft foot deformity with a suture-button construct in the pediatric foot: a case report. Foot Ankle Int 2013;34(9):1299-304. Crossref 